\title{
Pengaruh Pelatihan e-Faktur dan $Q R$ code scanner terhadap Kemampuan Soft skill Mahasiswa Akuntansi
}

\author{
Fatmawati Zahroh \\ Program Studi Akuntansi \\ UIN Maulana Malik Ibrahim \\ Malang, Indonesia
}

e-mail: fatmawati.zahroh.fe@uin-malang.ac.id ${ }^{* 1}$

Riwayat Artikel Tanggal diajukan: 26 September 2021

Tanggal diterima: 22 Oktober 2021

Tanggal dipublikasikan: 15 Desember 2021

Pengutipan: Zahro,Fatmawati. (2021). Pengaruh Pelatihan e-Faktur dan $Q R$ code Scanner terhadap Kemampuan Soft Skill Mahasiswa Akuntansi. Jurnal Pendidikan Ekonomi Undiksha,13(2), 364-376 http://dx.doi.org/1 $0.23887 /$ jipe.v13 2.39730

\begin{abstract}
Abstrak
Perpajakan selalu mengalami pembaharuan yang disebut reformasi perpajakan. Tidak hanya peraturan yang mengalami pembaharuan akan tetapi juga segala macam yang menyangkut transaksi bisnis yang berkaitan dengan pajak. Salah satunya yang baru diterapkan 1 Juli 2016 adalah pelaporan SPT Masa PPN dengan fakturnya yang menggunakan e-faktur. E-faktur ini fungsinya untuk mencegah adanya faktur pajak fiktif. Dunia kerja semakin berkembang seiring dengan perubahan-perubahan dalam system dan peraturan perpajakan yang terusmenerus mengalami perubahan perbaikan-perbaikan. Untuk itulah penelitian ini digunakan dalam rangka meningkatkan soft skill mahasiswa akuntansi supaya bisa bersaing saat lulus dan mencari kerja. Penelitian ini menggunakan metode eksperimen dengan mengadakan pelatihan e-faktur dan $Q R$ code scanner guna melihat perbedaan antara mahasiswa yang ditreatment dengan pelatihan dengan yang tidak. Dan hasilnya sangat signifikan berbeda sehingga hal ini berefek pada kemampuan soft skill yang dimiliki mahasiswa yang telah ditreatment pelatihan. Hasil penelitian menunjukkan bahwa tingkat signifikansi 0,000 artinya ada perbedaan signifikan yang terjadi dalam uji beda pengaruh pelatihan terhadap kemampuan soft skill mahasiswa akuntansi. Hal ini diharapkan bahwa adanya program berkelanjutan untuk mengasah soft skill mahasiswa bidang akuntansi supaya terasah soft skill yang dimiliki mahasiswa akuntansi dan mampu bersaing di dunia kerja.
\end{abstract}

Kata Kunci: Pelatihan Aplikasi Perpajakan; QR Kode; Kemampuan Softskill

\begin{abstract}
Taxation has always undergone a reform called tax reform. Not only the regulations that are undergoing reform but also all sorts of business transactions related to taxes. One of the new ones implemented July 1, 2016 is the reporting of VAT Period SPT with its invoices that use e-invoices. This e-invoice functions to prevent fictitious tax invoices from being ed. The world of work is growing as changes in the system and tax regulations are constantly changing. That's why this research is used in order to improve the soft skills of accounting students in order to compete when graduating and looking for work. The study used experimental methods by conducting e-invoice training and $Q R$ code scanners to see the difference between students who were treatment and those who did not. And the results are so significantly different that this has an effect on the soft skills that students who have been treatment training. The results showed that the significance level of 0,000 means there are significant differences that occur in the test of the different effects of training on the soft skills of accounting students. It is expected that there is an ongoing program to hone the soft skills of students in accounting so that they feel soft skills owned by accounting students and able to compete in the world of work.
\end{abstract}

Keywords : Tax Application Training; QR Code; Soft skill Capability 


\section{PENDAHULUAN}

Perpajakan di Indonesia berkali-kali mengalami pembaharuan. Reformasi pajak dilakukan dengan alasan untuk: pertama, jumlah pajak yang diterima oleh negara bergantung administrasi perpajakan yang efektif dan efisien. Kedua, iklim investasi sektor swasta menjadi tolok ukur kualitas administrasi perpajakan. Ketiga, korupsi menjadi khas pada instansi pajak dan bea cukai. Keempat mulai berkembang sektor bisnis dan tax avoidance (Gill, 2003). Reformasi termasuk semua lini dari peraturannya hingga pengaplikasiannya dari segi pelaporan pajaknya dan segala hal yang berkaitan dengan aktivitas bisnis yang berhubungan dengan pajak. Faktur Pajak adalah bukti penyerahan barang kena pajak dan jasa kena pajak yang terkena PPN saat melakukan penjualan (Mardiasmo, 2018). Faktur Pajak dibuat pada: saat penjualan/ pembelian BKP/ JKP; munculnya di kala penerimaan pembayaran sebelum pembelian/ penjualan BKP/ JKP; penerimaan pembayaran dalam termin/ kredit, pengerjaannya dilakukan sebagian; dan saat hal lain yang diatur dalam Peraturan Menteri Keuangan.

Dalam Keputusan Menteri Keuangan Nomor 432/KMK.04/1984 diatur mengenai faktur pajak untuk pertama kali. Pada tahun 1984, pengisian faktur manual dengan satu jenis. Pada tahun 1985 penerbitan faktur pajak sederhana bagi pengusaha ecer untuk barang jadi, kemudian peraturan ini dicabut tahun 2012 (faktur pajak sederhana).

Pada tahun 2013 Dirjen Pajak membuat E-Tax Invoice (e-Faktur) aplikasi berbasis elektronim untuk membuat faktur pajak yang desediakan oleh Dirjen Pajak ini untuk mengurangi faktur pajak fiktif, efaktur. e-Faktur adalah faktur elektronik yang disediakan oleh Direktorat Jenderal Pajak (Sakti and Hidayat 2015). Aplikasi yang diakses Pengusaha Kena Pajak (PKP), mereka diwajibkan membuat SPT masa PPN dengan aplikasi tersebut. Dengan adanya SPT dalam aplikasi eFaktur, PKP dapat membuat SPT Masa PPN menggunakan data input Faktur Pajak dan dokumen lainnya, melengkapi formulir SPT yang sudah terbentuk dan membuat file CSV yang sama dengan bentuk SPT Masa PPN 1111 untuk pelaporan ke Kantor Pelayanan Pajak (KPP).

Faktur Pajak Elektronik adalah bukti elektronik saat penyerahan BKP/JKP yang terkena pajak sebagaimana yang dimaksud dalam pasal 4 ayat (1) huruf a dan huruf c serta Pasal 16D UU PPN 1984 (Sukardji, 2015). Faktur pajak berbentuk elektronik, yang selanjutnya disebut efaktur, adalah bukti faktur dalam aplikasi yang ditentukan dan/atau disediakan oleh Direktorat Jenderal Pajak (Pohan, 2017).

Sedangkan e-invoice adalah sejenis layanan sistem informasi yang mengumpulkan informasi transaksi dan mengirimkannya melalui internet. Di era ecommerce ini, E-invoice berperan penting dalam menyediakan informasi berupa data semua transaksi bisnis yang diperlukan (Chang et al., 2013). Electronic Data Interchange (EDI) awalnya hanya diterapkan antar bisnis. Belakangan ini Internet digunakan untuk mengirimkan $e$ invoice antara individu, bisnis, dan pemerintah,serta menjadi andalan untuk ecommerce. Saat ini, banyak negara telah menggunakan komputasi awan untuk menyediakan layanan faktur elektronik bagi semua pemangku kepentingan. Dibandingkan dengan faktur kertas biasa, faktur elektronik dapat membantu pebisnis dalam bertransaksi tanpa kertas dan transparan. Banyak penelitian sebelumnya telah memperhatikan adopsi faktur elektronik. Namun, kebanyakan dari mereka berfokus pada tingkat bisnis / perusahaan (Hernández-Ortega, 2011; Vrček \& Magdalenić, 2011). Jadi dapat disimpulkan, bahwa elektronik faktur pajak (e-faktur) adalah sebuah program aplikasi sistem elektronik yang disediakan oleh Direktorat Jendral Pajak kepada Pengusaha Kena Pajak dalam membuat faktur pajak secara elektronik, baik itu berupa penyetoran dari Barang Kena Pajak dan/atau Penyetoran dari Jasa Kena Pajak.

Tahapan penggunaan aplikasi efaktur oleh PKP yaitu mulai tanggal 1 Juli 2014, diberlakukan kepada 45 Pengusaha Kena Pajak. Mulai tanggal 1 Juli 2015, diberlakukan kepada PKP yang terdaftar di lingkungan Kantor Wilayah DJP Wajib Pajak Besar, DI Jakarta, Banten, Jawa 
Barat, Jawa Tengah, Jawa Timur, DI Yogyakarta dan Bali, sedangkan tanggal 1 Juli 2016, baru diberlakukan secara nasional.

Jika dilihat dari kegiatan yang dilakukan akuntan di dalam perusahaan itu harus selalu mengikuti perkembangan jaman, dari pengetahuan UU Perpajakan terbaru, pelatihan untuk peningkatan profesi akuntan sampai penggunakan fitur online. Seperti e-faktur ini merupakan salah satu dari banyak aplikasi yang dibuat oleh KPP guna mempermudah para wajib pajak dalam hal pembuatan faktur elektronik. Untuk kelancaran proses transaksi bisnis, banyak negara telah menerapkan sistem efaktur; contohnya Denmark, Swedia dan Finlandia (Chang et al., 2013; Partland, 2013). Seiring perkembangan e-commerce secara bertahap menjadi hal biasa di Taiwan, perusahaan mulai bertukar informasi transaksi melalui internet. Pada tahun 2000, Ministry of Finance Taiwan (MOF) melakukan proof of concept (POC) untuk e-faktur business-to-business (B2B). Kemudian, pada tahun 2004, MOF mengusulkan proyek awal dari e-faktur dengan tujuan untuk mengurangi jumlah faktur berbasis kertas. Dalam dekade terakhir, platform e-faktur telah digunakan dan dikembangkan untuk meningkatkan efaktur business-to-government (B2G), B2B dan business-to-consumer (B2C). Setelah berkembang lebih dari dua generasi, platform tersebut telah berkembang hampir 1,9 miliar faktur dari lebih dari 30.000 perusahaan, termasuk 105 distributor (Lee \& Wang, 2013; MOF, 2014). Penerapan sistem e-faktur dapat dianggap sebagai perubahan paradigma dalam perjalanan bisnis menangani transaksi; e-faktur juga terdiri dari komponen bisnis transaksi, yang akan menyertai rekayasa ulang proses bisnis (Chen et al., 2015).

Dengan kemampuannya yang dapat memberikan kemudahan, dan layanan yang cepat, $Q R$ Code dimanfaatkan pula dalam bidang perpajakan, khususnya menyajikan kemudahan dalam penyerahan faktur pajak. Jadi, Faktur pajak sudah tidak lagi dilaporkan atau diserahkan secara manual, tapi harus melalui aplikasi e-Faktur yang terkoneksi secara otomatis dengan server Direktorat Jenderal Pajak (DJP).
Sistem berbasis elektronik tersebut, mampu memberikan keunggulan lain, yaitu menghindari terjadinya kecurangan atau adanya pembuatan faktur pajak fiktif. Faktur pajak elektronik ini telah berlaku untuk seluruh wajib pajak di Indonesia sejak Juli 2016.

$Q R$ Code menyimpan alamat situs DJP yang memuat berbagai informasi dan data yang berkaitan dengan verifikasi terhadap faktur pajak, sehingga ketika $Q R$ Code tersebut di Scan oleh pihak Penjual, maka secara otomatis sistem akan melakukan validasi secara online terhadap faktur pajak sehingga keamanan (karena terindungi dari penyalahgunaan faktur pajak yang tidak valid), kenyamanan (karena pihak pembeli mendapat kepastian PPN yang dibayarkan, telah dilaporkan secara otomatis oleh pihak penjual), keaslian dokumen faktur pajak, dan kemudahan penyerahan faktur pajak benar benar terwujud dan terjaga (Rafinska, 2018) dari online-pajak.com.

Barcode juga digunakan dalam fitur ini. Untuk mengecek valid tidaknya e-faktur yang diterbitkan oleh PKP (Pengusaha Kena Pajak), konsumen bisa menggunakan fitur $Q R$ code scanner. Di situs resmi pajak.go.id telah disebutkan banyak informasi mengenai e-faktur yang peraturannya telah diberlakukan di 2015. Perusahaan besar telah berbondongbondong untuk mengkaji informasi ini dan memberikan pelatihan kepada karyawan terkait dengan pekerjaan tersebut yaitu akuntannya untuk update kemampuan dalam penguasaan fitur pajak digital, dalam hal ini adalah e-faktur.

Berdasarkan pengamatan Penulis dan teman sejawat yang dilakukan selama ini, dosen dan mahasiswa kurang mengupdate informasi mengenai kemajuan teknologi dalam bidang perpajakan, semuanya masih dilakukan secara manual. Sebenarnya yang terjadi di lingkungan kampus terutama di prodi akuntansi ini, semua pembahasan mengenai perhitungan hingga pelaporan pajak masih menggunakan teori yang ada di buku, tidak update informasi di web resmi pajak maupun tidak menggunakan fitur digital pelaporan pajaknya. Perangkat dan media serta simulasi digital yang tidak update ini 
menjadi kendala besar bagi para pengajar mata kuliah perpajakan, sehingga hal ini membuat kami sangat tertinggal dengan dunia luar. Apalagi fitur e-faktur ini tidak bisa disimulasikan offline, jadi harus riil perusahaan yang telah ditetapkan menjadi PKP saja yang bisa menggunakan fitur efaktur yang ada di situs. Sehingga kendala ini dibuatkan solusi oleh karyawan KPP, yakni mereka mempunyai fitur dummy efaktur (fitur offline untuk simulasi e-faktur).

Untuk itulah Peneliti dalam hal ini ingin meningkatkan soft skill mahasiswa prodi akuntansi. Peneliti mendefinisikan soft skill sebagai seperangkat kemampuan profesional non teknis seperti komunikasi dan keterampilan antar pribadi dan ciri-ciri pribadi seperti integritas yang seharusnya memiliki keterampilan keras atau teknis seperti pengetahuan di bidang TI dalam layanan terkait profesi (Matteson et al., 2016). Keterampilan lunak juga dikenal sebagai keterampilan umum,dan keterampilan dasar. Soft skill adalah ciri pribadi yang meningkatkan kepribadian seseorang, interaksi, keterampilan komunikasi dan prestasi kerja, dan itu penting dalam memajukan karir individu (Pazhani \& Priya, 2012). Secara luas, kita dapat mengatakan bahwa soft skill terdiri dari konsep-konsep seperti skills, disposition, attitudes, believes dan values. Kesadaran dan pengakuan akan pentingnya soft skill semakin meningkat beberapa tahun terakhir. Saat ini, calon pemberi kerja sering kali menempatkan kualitas / keterampilan seperti "team work, communication and self-skills above knowledge, degree classification, intelligence and reputation of the institute the graduate attended" (Frantz. \& Missal., 2016).

Keterampilan kerja dapat didefinisikan sebagai:

[. . .] a set of achievements - skills, understandings and personal attributes that make graduates more likely to gain employment and be successful in their chosen occupations, which benefit themselves, the workforce, the community and the economy (Saunders \& Zuzel, 2010).

Pada intinya, ini melibatkan
pemahaman
tentang

menyelaraskan antara kelayakan kerja dengan akademis, nilai-nilai dengan kurikulum dan menghubungkan kemampuan kerja dengan kebutuhan industri. Pelatihan soft skill harus dimasukkan ke dalam kurikulum pendidikan tinggi dan terintegrasi dengan pelatihan teknis (ASTD, 2012).

(Laker \& Powel, 2011) menekankan, bahwa miskinnya pemberian pelatihan soft skill daripada hard skill di dunia kerja, akan mengakibatkan banyak buang waktu dan energi, serta menghabiskan biaya yang sangat banyak. Soft skill harus menjadi bagian yang integral dengan pembelajaran, harus mendapat tempat dalam kurikulum, dan harus menjadi bagian yang tak terpisahkan pada setiap tahapan jenjang karir seseorang. Keterampilan lunak adalah keterampilan hidup yang dibutuhkan di setiap sendi kehidupan pribadi dan kehidupan profesional untuk menjadi manusia dan pekerja yang lebih baik (Sethi, 2018).

Universitas telah berusaha untuk mengintegrasikan soft skill ke dalam kurikulum, tetapi dihadapkan pada kendala tertentu (Tran, 2013). Tran menemukan bahwa mahasiswa dan alumni tidak puas dengan pengembangan soft skill di universitas mereka, kurikulum universitas yang ketinggalan jaman yang tidak mendukung pengembangan keterampilan tenaga kerja modern, menitikberatkan pada ujian berbasis pengetahuan, lemahnya penilaian keterampilan yang dipelajari dan miskinnya kegiatan ekstrakurikuler, yang semuanya berkontribusi pada minimnya dukungan terhadap pengembangan soft skill. Para mahasiswa dalam studinya Tran, juga berharap soft skill ini diajarkan sebagai subjek yang terpisah, gagal dalam melihat hubungan antara terlibat aktif di kelas dan pengembangan soft skill.

(Yao \& Tuliao, 2019) temuan temuan dalam studi ini, berkontribusi dalam memahami bagaimana lembaga/institusi transnasional dapat memelihara kemampuan kerja dan jaminan diri yang dirasakan dari lulusan di masa depan dalam mengantarkan pada pasar kerja yang semakin kompleks sebagai cara untuk memenuhi kebutuhan akan soft skill 
pada tenaga kerja di negara-negara seperti Vietnam. Dengan memperhatikan pengalaman-pengalaman mahasiswa pascasarjana, kita bisa memahami tantangan dan peluang bagi mahasiswa di universitas-universitas transnasional, terutama yang berhubungan dengan tujuan profesional dan prioritas nasional mereka.

Soft skill belum dikembangkan dengan baik sebagai disiplin akademis (Truong \& Laura, 2015), meskipun ini pertama kali disinggung lebih dari 45 tahun yang lalu pada tahun 1972 (Rao, 2014). Bahkan, soft skill sulit diukur menggunakan tes (Mar, 2016). Peneliti memiliki definisi yang berbeda-beda. Berdasarkan (Han, 2011) harus ada tiga atribut dalam suatu keterampilan agar dianggap sebagai soft skill, yaitu portabilitas dan nilai untuk pekerjaan apa pun, menguasai keterampilan itu area abu-abu dan menguasainya adalah proses yang berkelanjutan. Soft skill adalah istilah sosiologis (Sheeta, 2013) ini disebut dengan personal skill (Chaudhry et al., 2008; Sheeta, 2013; Truong \& Laura, 2015) dengan interpersonal skills (Robles, 2012) dan career attributes (Mitchell, 2010; Robles, 2012; Sheeta, 2013).

Peneliti mencatatkan soft skill sebagai keterampilan yang berbeda sebagaimana keterampilan komunikasi, kemampuan untuk bekerja dalam tim (Chaudhry et al., 2008; Jolly, 2012; Mitchell, 2010; Truong \& Laura, 2015), kemampuan untuk menunjukkan ethical standards (Jolly, 2012; Mitchell, 2010), problem-solving skill dan leadership skill (Jolly, 2012; Truong \& Laura, 2015). Selain keterampilan tersebut, peneliti juga menyebutkan keramahan, keterampilan menyimak yang baik (Truong \& Laura, 2015), time management skill (Chaudhry et al., 2008; Mitchell, 2010), appreciation for diversity, long life learning, entrepreneurship skill dan information management skill (Chaudhry et al., 2008).

Berdasarkan literatur dari kerangka kompetensi South African Institute of Chartered Accountants (SAICA., 2014), mahasiswa akuntansi perlu mengembangkan 12 pervasive skills, yaitu: communication (verbal); communication (listening); communication (writing); problem-solving; teamwork; time management; leadership; professionalism; ethical awareness; strategic thinking; critical thinking; dan influencing others.

Dengan beberapa faktor soft skill yang disebutkan beberapa penelitian di atas, maka Peneliti mengambil 5 faktor yang cocok untuk penelitian ini yaitu (1) problem solving, (2) time management, (3) profesionalism, (4) ethical awareness, (5) strategic thinking.

Dalam penelitian (Maria et al., 2018) disebutkan, bahwa e-faktur dapat membantu pembuatan faktur pajak dalam perusahaan sehingga dapat mempermudah dalam pembuatan e-filling. Sedangkan menurut (Setyawati et al., 2016) penerapan Sistem Elektronik Nomor Faktur (e-nofa) dengan merancang, membangun sistem informasi dan aplikasi, Sosialisasi dan Pelatihan Sistem E-NOFA, Penerapan Sistem Elektronik Nomor Faktur (e-NOFA), Pengawasan Sistem ENOFA, Evaluasi Penerapan Sistem ENOFA harus dijalankan dengan baik agar dapat mencegah terjadinya faktur pajak fiktif, sedangkan menurut (Laela, 2018), untuk mencegah adanya human error yang menyebabkan upload e-faktur terkendala.

Adanya pelatihan penggunaan aplikasi di android sangat berguna bagi UMKM untuk mempermudah bisnisnya (Rahmawati et al., 2018). Sedangkan menurut (Damayanti et al., 2018) adalah untuk menyiapkan mahasiswa dalam menghadapi dunia kerja mendatang dengan pelatihan sertifikasi zahir accounting sehingga mahasiswa menjadi unggul dan dapat mengasah kemampuannya. Serta menurut (Sukowidyanti et al., 2019) menghasilkan penelitian berupa permainan edukasi perpajakan, efektif dalam meningkatkan pengetahuan dan kesadaran akan pajak, permainan edukasi perpajakan juga masih memungkinkan untuk terus dikembangkan.

Dari penjelasan di atas dan yang melatarbelakangi penelitian ini serta adanya penelitian terdahulu tentang pengaruh pelatihan berbagai macam jenis software perpajakan maupun aplikasi perpajakan maka memunculkan masalah bagaimana pengaruh pelatihan e-faktur dan $Q R$ code scanner terhadap soft skill 
mahasiswa Akuntansi? Penelitian ini dimaksudkan berkontribusi dalam pengembangan soft skill mahasiswa akuntansi untuk menghadapi dunia kerja yang semakin modern dan aplikatif dalam menggunakan software yang mendukung bidang kerjanya.

\section{METODE}

\section{Desain Eksperimen}

Penelitian eksperimen merupakan penelitian kausal (sebab akibat) yang di dalamnya terdapat perlakuan khusus yang diberikan oleh Peneliti kemudian diamati dan diukur dampaknya. Pembuktian eksperimen melalui perbandingan antara: Kelompok eksperimen yang diberikan perlakuan dan kelompok kontrol yang tidak diberikan perlakuan atau, Kondisi subjek sebelum diberikan perlakuan dan sesudah perlakuan.

Ruang Lingkup Penelitian Eksperimen yaitu: Penelitian digunakan dalam rangka melakukan inovasi untuk meningkatkan kualitas pembelajaran. Biasanya dalam hal menguji pengaruh materi, media, metode atau praktik pendidikan baru; dan rancangan eksperimen menggunakan variabel tunggal (Jaedun, 2011).

Sedangkan design penelitian yang digunakan adalah Matching-Pretest-Post test Control Group Design, yaitu jenis eksperimen terdapat dua kelas secara langsung kemudian diberi pretest untuk mengetahui keadaan awal adakah kelas eksperimen dan kelas kontrol (Sugiyono., 2019). Kemudian menggunakan bentuk Matching Pretest Post test Comparison Group Design yaitu eksperimen dengan satu macam perlakuan dalam hal ini pelatihan.

Penelitian ini bertujuan untuk mengetahui tidak ada perbedaan antara kelompok kontrol dengan kelompok eksperimen sehingga akan menghasilkan kemampuan yang sama dalam mengerjakan soal. Designnya adalah sebagai berikut:

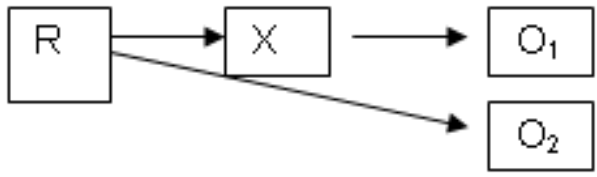

\section{Gambar 1. Desaign Penelitian}

$\mathrm{R}$ adalah subjek penelitian yang dilakukan secara acak menjadi 2 kelas. $O$ menunjukkan pengukuran/aktivitas observasi. Sedangkan $X$ adalah kemunculan stimulus berupa pelatihan dalam 1 kelompok eksperimental sedangkan 1 lagi kelompok kontrol tidak mendapatkan pelatihan.

Sesuai dengan design eksperimen tersebut maka pelaksanaan eksperimen penelitian ini adalah sebagai berikut: yang pertama, subjek eksperimen (mahasiswa akuntansi semester 7) dibagi menjadi 2 kelompok yaitu kelompok 1 adalah kelompok kontrol dan kelompok 2 adalah kelompok eksperimental; yang kedua, kelompok 1 dan 2 diberikan soal latihan (pretest) untuk mengetahui apakah ada perbedaan kemampuan dalam mengerjakan soal perpajakan dalam hal ini e-faktur dan $Q R$ code scanner; yang ketiga, kemudian kelompok 2 mendapatkan pelatihan sedangkan kelompok 1 tidak mendapatkan pelatihan; yang keempat, post test hanya dilakukan pada kelompok 2 karena telah diberikan pelatihan; yang kelima, kelompok 1 dan 2 diberikan kuesioner untuk mengukur soft skill (setelah mengerjakan post test).

Identifikasi Stimulus (treatment) dan Outcome

Stimulus (treatment) atau variabel independen dimanipulasi dalam eksperimen ini, yaitu dengan melakukan sosialisasi dan pelatihan e-faktur dan $Q R$ code scanner. Sedangkan variabel dependen dalam eksperimen ini adalah soft skill mahasiswa akuntansi. Terdapat 5 jenis faktor yang mempengaruhi soft skill mahasiswa setelah mendapatkan pelatihan yaitu : (1) problem solving, (2) time management, (3) profesionalism, (4) ethical awareness, (5) strategic thinking. Soft skill ini diukur dengan skala likert 1 sampai dengan 5 .

Teknik Analisis Data

Penelitian ini menggunakan kualitatif dan kuantitatif. Kualitatif dengan menggunakan penelitian tindakan kelas dengan pretest dan post test menggunakan soal latihan. Kemudian menggunakan 
kuantitatif untuk menguji soft skill mahasiswa. Hipotesis ini menguji $t$ perbedaan beberapa faktor dari soft skill. Ekuivalen kelompok 1 dan 2 sebelum eksperimen diuji dengan MANOVA terhadap faktor soft skill yaitu (1) problem solving, (2) time management, profesionalism, (4) ethical awareness, (5) strategic thinking.

Populasi dan Sample

Populasi subjek penelitian ini yaitu mahasiswa akuntansi semester 7 di UIN Maulana Malik Ibrahim Malang. Sampel diambil menjadi subjek penelitian. Pengambilan sample dilakukan dengan metode purposive sampling yaitu dikhususkan bagi mahasiswa semester 7 akuntansi yang telah menempuh mata kuliah perpajakan dengan tujuan mengerti teori perpajakan secara umum, diharapkan tidak bias karena sudah memiliki dasar pengetahuan perpajakan.

\section{HASIL DAN PEMBAHASAN}

Uji Ekuivalensi Kelompok Kontrol dan Kelompok Eksperimen Sebelum Perlakuan

Penelitian ini dibagi menjadi 2 kelompok, 1 kelompok mengerjakan soal PPN masukan dan keluaran tanpa adanya pelatihan menggunakan e-faktur dan kelompok 2 sebelum mengerjakan soal dilakukan sosialisasi dan pelatihan terlebih dahulu.

Kelompok 1 terdiri dari 20 mahasiswa semester 7 kelas $C$ tidak mendapatkan sosialisasi dan pelatihan e-faktur dan $Q R$ code scanner yang hasilnya tidak ada satupun mahasiswa yang dapat mengerjakan soal PPN masukan dan keluaran yang memakai aplikasi e-faktur, dan menggunakan $Q R$ code scanner juga bingung.

Untuk menguji bahwa tidak ada perbedaan kemampuan yang dimiliki mahasiswa yang kelas kontrol maupun eksperimen maka dilakukan uji beda menggunakan MANOVA kelompok 1 dan 2 sebelum melakukan eksperimen:

Tabel 1. Uji t MANOVA sebelum eksperimen

\begin{tabular}{ccc}
\hline $\begin{array}{c}\text { Karakteristik } \\
\text { yang Diuji }\end{array}$ & $\begin{array}{c}\text { W } \\
\text { (Wilks } \\
\text { Lambda) }\end{array}$ & (sig) \\
\hline
\end{tabular}

\begin{tabular}{lll}
\hline Problem Solving & 0.9011 & 0.0481 \\
Time & 0.9953 & 0.6730 \\
Management & 0.9083 & 0.0496 \\
Profesionalism & 0.9814 & 0.4015 \\
Ethical & 0.9774 & 0.3550 \\
Awareness & & \\
\multicolumn{2}{c}{ Strategic Thinking } \\
\multicolumn{2}{c}{ Dalam tabel 1 dapat } & dijelaskan
\end{tabular}
bahwa signifikansi yang $\mathrm{F} \mathrm{Sig}>0,05$ adalah Time Management (0.6730); Ethical Awareness (0.4015) dan Strategic Thinking (0.3550) yaitu tidak signifikan yang berarti bahwa tidak ada perbedaan kemampuan soft skill antara kelompok 1 dan kelompok 2 sebelum eksperimen. Artinya bahwa 3 faktor ini tidak ada bedanya dengan atau tanpa pelatihan. Karena biasanya time management terbentuk akibat adanya control waktu dari masing-masing peserta yang memang sudah terbiasa dengan on time. Yang kedua bahwa ethical awareness adalah sikap yang sudah terbentuk dari awal karena takut untuk mencontek. Yang ketiga adalah strategic thinking ini sudah terbentuk sejak awal yaitu dengan memiliki strategi berpikir yang terbentuk karena telah menempuh latihan-latihan dalam praktikum.

Dalam tabel 1 juga menyebutkan bahwa F Sig $<0,05$ adalah Problem Solving (0.0481) dan Professional (0.0496) yaitu terdapat signifikansi yang berarti bahwa ada perbedaan kemampuan soft skill antara kelompok 1 dan kelompok 2 sebelum eksperimen. Dalam penelitian ini berarti bahwa sikap problem solving yaitu sikap memiliki cara untuk mencari jalan keluar yang dihadapi ini belum terasah jika belum melalui pelatihan. Yang kedua adalah professional yaitu belum adanya sikap professional/ahli dalam pengelolaan e-faktur dan $Q R$ code scanner jika belum diadakan pelatihan.

Pengaruh Pelatihan e-Faktur dan $Q R$ code scanner terhadap Soft skill Mahasiswa Akuntansi

Pengaruh pelatihan terhadap soft skill ini diuji dengan membandingkan soft skill subjek eksperimen kelompok 1 dan 2 melalui uji t perbedaan 2 mean. Hasil $t$ untuk kelima jenis soft skill yang diukur disajikan pada tabel 2 berikut ini: 
Tabel 2. Uji t MANOVA setelah pelatihan

\begin{tabular}{lll}
\hline Karakteristik yang Diuji & W (Wilks Lambda) & $\mathrm{F}(\mathrm{sig})$ \\
\hline Problem Solving & 0.0130 & 0.0000 \\
Time Management & 0.0209 & 0.0000 \\
Profesionalism & 0.0657 & 0.0000 \\
Ethical Awareness & 0.0582 & 0.0000 \\
Strategic Thinking & 0.0385 & 0.0000 \\
\hline
\end{tabular}

Dalam tabel 2 menyebutkan bahwa $\mathrm{F}$ Sig $<0,05$ yang berarti bahwa ada perbedaan soft skill di semua jenis artinya yaitu ada perbedaan signifikan antara kelompok 1 dan kelompok 2 setelah dilakukan pelatihan.

Tabel 3. Nilai PPN Masukan dan Keluaran setelah Pelatihan Daftar Nilai Pelatihan E-Faktur

\begin{tabular}{|c|c|c|c|c|c|c|c|}
\hline No & Nama & $\begin{array}{c}\text { PPN } \\
\text { Keluaran }\end{array}$ & $\begin{array}{c}\text { PPN } \\
\text { Masukan }\end{array}$ & $\begin{array}{c}\text { Retur } \\
\text { Penjuala } \\
n\end{array}$ & $\begin{array}{c}\text { Retur } \\
\text { Pembeli } \\
\text { an }\end{array}$ & $\begin{array}{c}\text { Laporan PPN } \\
\text { Masukan dan } \\
\text { Keluaran }\end{array}$ & $\begin{array}{c}\text { e-SPT } \\
\text { Masa } \\
\text { PPN }\end{array}$ \\
\hline 1 & $\begin{array}{l}\text { Gusti Fahmi } \\
\text { Saputra } \\
\text { Wijayanto }\end{array}$ & 90 & 90 & 88 & 88 & 88 & 88 \\
\hline 2 & $\begin{array}{l}\text { Muhammad } \\
\text { Misbakhur } \\
\text { Rozaq }\end{array}$ & 90 & 90 & 87 & 87 & 87 & 87 \\
\hline 3 & $\begin{array}{l}\text { Elys } \\
\text { Wanudya } \\
\text { Purba } \\
\text { Laksmi }\end{array}$ & 90 & 90 & 90 & 90 & 90 & 90 \\
\hline 4 & $\begin{array}{l}\text { Ragil Ariftian } \\
\text { Sugiarti }\end{array}$ & 90 & 90 & 90 & 90 & 90 & 90 \\
\hline 5 & $\begin{array}{l}\text { Nizar Ali } \\
\text { Sahab }\end{array}$ & 90 & 90 & 87 & 87 & 87 & 87 \\
\hline 6 & $\begin{array}{l}\text { Bella Gita } \\
\text { Aditya }\end{array}$ & 90 & 90 & 88 & 88 & 89 & 89 \\
\hline 7 & $\begin{array}{l}\text { Rino } \\
\text { Taufiqorroch } \\
\text { man }\end{array}$ & 90 & 90 & 89 & 89 & 89 & 89 \\
\hline 8 & $\begin{array}{l}\text { Afiq Chamim } \\
\text { Mubaroq }\end{array}$ & 90 & 90 & 90 & 90 & 90 & 90 \\
\hline 9 & $\begin{array}{l}\text { Mukhamad } \\
\text { Akbar } \\
\text { Royyansyah }\end{array}$ & 90 & 90 & 90 & 90 & 90 & 90 \\
\hline 10 & $\begin{array}{l}\text { Zulasfi } \\
\text { Waraihan }\end{array}$ & 90 & 90 & 90 & 90 & 90 & 90 \\
\hline 11 & $\begin{array}{l}\text { Muhammad } \\
\text { Nurdin }\end{array}$ & 88 & 88 & 87 & 87 & 87 & 87 \\
\hline 12 & Atik Fitria & 90 & 90 & 90 & 90 & 90 & 90 \\
\hline 13 & $\begin{array}{l}\text { Luluk } \\
\text { Aribatul } \\
\text { Karimah }\end{array}$ & 90 & 90 & 88 & 88 & 88 & 88 \\
\hline
\end{tabular}




\begin{tabular}{|c|c|c|c|c|c|c|c|}
\hline$\overline{14}$ & $\begin{array}{l}\text { Adam } \\
\text { Axelrio } \\
\text { Hartoyo }\end{array}$ & 90 & 90 & 87 & 87 & 87 & 87 \\
\hline 15 & $\begin{array}{l}\text { M. Haris } \\
\text { Abdul Malik }\end{array}$ & 90 & 90 & 87 & 87 & 87 & 87 \\
\hline 16 & $\begin{array}{l}\text { Laily } \\
\text { Nursani }\end{array}$ & 90 & 90 & 90 & 90 & 90 & 90 \\
\hline 17 & $\begin{array}{l}\text { Dwi Nabila } \\
\text { Putri }\end{array}$ & 90 & 90 & 90 & 90 & 90 & 90 \\
\hline 18 & $\begin{array}{l}\text { M. Khairul } \\
\text { Huda }\end{array}$ & 90 & 90 & 88 & 88 & 88 & 88 \\
\hline 19 & $\begin{array}{l}\text { Lulu IImang } \\
\text { S. }\end{array}$ & 90 & 90 & 90 & 90 & 90 & 90 \\
\hline 20 & $\begin{array}{l}\text { Yoga Taufan } \\
\text { Fahma }\end{array}$ & 90 & 90 & 88 & 88 & 88 & 88 \\
\hline
\end{tabular}

Dalam tabel 3 di atas menggambarkan bahwa nilai mahasiswa akuntansi hampir sempurna dalam mengerjakan soal setelah mendapatkan sosialisasi dan pelatihan e-Faktur dan $Q R$ code scanner.

\section{SIMPULAN DAN SARAN}

Pada saat uji ekuivalensi antara kelompok kontrol dan kelompok eksperimen sebelum perlakuan memiliki signifikansi yang $\mathrm{F} \mathrm{Sig}>0,05$ adalah Time Management (0.6730); Ethical Awareness (0.4015) dan Strategic Thinking (0.3550) yaitu tidak signifikan yang berarti bahwa tidak ada perbedaan kemampuan soft skill antara kelompok 1 dan kelompok 2 sebelum eksperimen. Artinya bahwa 3 faktor ini tidak ada bedanya dengan atau tanpa pelatihan, yaitu manajemen waktu (mahasiswa mampu memanajemen waktu dengan baik), mahasiswa juga mempunyai kesadaran etis untuk berbuat jujur serta memiliki strategi pemikiran yang tertata dengan baik. Sedangkan Problem Solving (0.0481) dan Professional (0.0496) yaitu terdapat signifikansi yang berarti bahwa ada perbedaan kemampuan soft skill antara kelompok 1 dan kelompok 2 sebelum dan setelah eksperimen. Problem solving merupakan cara mahasiswa dalam menganalisa dan memberikan solusi serta keputusan dalam suatu masalah dan juga professional yang berarti bahwa keahlian dalam menjalankan software sangatlah berbeda antara sebelum dan sesudah pelatihan.

Kemudian setelah diuji beda hasilnya bahwa F Sig<0,05 yang berarti bahwa ada perbedaan soft skill di semua jenis artinya yaitu ada perbedaan signifikan antara kelompok 1 dan kelompok 2 setelah dilakukan pelatihan

Penulis menyadari bahwa ada banyak keterbatasan yang dimiliki dalam penulisan penelitian ini, adapun keterbatasannya adalah sebagai berikut:

1. Perlakuan treatment tidak menyeluruh di jurusan akuntansi, hanya dipilih 2 kelas yang berisikan masing-masing kelompok kontrol dan kelompok treatment adalah 20 mahasiswa.

2. Penelitian ini hanya terbatas pada mahasiswa jurusan akuntansi di UIN Maulana Malik Ibrahim Malang.

Pengamatan Penulis dengan rekan sejawat bahwa masih banyak informasiinformasi terkini yang perlu dipelajari, apalagi dengan zaman yang serba digital seperti ini diperlukan soft skill guna menambah pengetahuan dan nilai tambah bagi mahasiswa yang akan terjun dalam dunia kerja. Dunia kerja sudah bergerak cepat dalam mengikuti perkembangan zaman. Perlu adanya sinkronisasi ilmu dan praktek yang memadai antara konsultan pajak, dosen pengampu mata kuliah dan mahasiswa. Sehingga terjalin komunikasi dan kerjasama yang saling menguntungkan dengan beberapa pihak 
tersebut. Diharapkan bahwa adanya program berkelanjutan untuk mengasah soft skill mahasiswa bidang akuntansi supaya terasah soft skill yang dimiliki mahasiswa akuntansi dan mampu bersaing di dunia kerja.

\section{DAFTAR PUSTAKA}

astd. (2012). "Bridging The Skills Gap", American Society For Training And Development.

Www.Nist.Gov/Sites/Default/Files/ Documents/Mep/Bridging-TheSkills-Gap_2012.Pdf

Chang, C.-J., Kuo, H.-C., Chen, C.-Y., Chen, T.-H., \& Chung, P.-Y. (2013). Ergonomic Techniques For A Mobile E-Invoice System: Operational Requirements Of An Information Management System. Human Factors And Ergonomics In Manufacturing \& Services Industries, 23(6), 582-589. Https://Doi.Org/10.1002/Hfm.2034 0

Chaudhry, A. S., Khoo, C. S. G., Wu, P., \& Chang, Y.-K. (2008). Trends In Lis Education: Coverage Of Soft Skills In Curricula. Journal of Librarianship And Information Studies, 66(66), 1-13. Http://Search.Proquest.Com/Docvi ew/57729757? Accountid=17252\% 5cnhttp://217.13.120.161:9004/Uc 3m?Url_Ver=Z39.88-

2004\&Rft_Val_Fmt=Info:Ofi/Fmt:K ev:Mtx:Journal\&Genre=Article\&Si $\mathrm{d}=$ Proq:Proq:Lisashell\&Atitle=Tren ds+In+Lis+Education:+Coverage+ Of+Soft+Skills+In+

Chen, S. C., Wu, C. C., \& Miau, S. (2015). Constructing An Integrated E-Invoice System: The Taiwan Experience. Transforming Government: People, Process And Policy, 9(3), 370-383. Https://Doi.Org/10.1108/Tg-092014-0043
Damayanti, M., Ria, A., \& Zainuddin, D. (2018). Pengaruh Pelatihan Sertifikasi Zahir Accounting Terhadap Kesiapan Kerja Mahasiswa Program Studi Pendidikan Ekonomi. Proceeding.Unindra.Ac.ld, 212216.

Http://Proceeding.Unindra.Ac.Id/In dex.Php/Dispanas2018/Article/Vie wfile/42/31

Frantz., \& Missal. (2016). Identification Of Generic Skills For Human Resources In Hospitality: A Literature Review. Journal For Contemporary Research In Management, 36-41.

Gill, J. B. S. (2003). Revenue Administration Reform. History, January.

Han, L. (2011). Soft Skills List - 28 Skills To Working Smart. Soft Skills - Ask A Wharton Mba. Https://Bemycareercoach.Com/Sof t-Skills/List-Soft-

Skills.Html\%0ainternal-

Pdf://250/List-Soft-Skills.Html

Hernández-Ortega, B. (2011). The Role Of Post-Use Trust In The Acceptance Of A Technology: Drivers And Consequences. Technovation, 31(10-11), 523538.

Https://Doi.Org/10.1016/J.Technov ation.2011.07.001

Jaedun, A. (2011). Metodologi Penelitian Eksperimen. Lpmp.

Jolly, S. S. (2012). Developing Soft Skills For Enhancing Employability Of Engineering Graduates. International Journal Of Engineering And Management Research, 2(5), 54-56.

Laela, E. T. (2018). Kendala Implementasi E-Faktur Pada Pt. Pmti. Festival Riset IImiah 
Manajemen \& Akuntansi, 940-947.

Laker, D. R., \& Powel, J. L. (2011). The Differences Between Hard And Soft Skills And Their Relative Impact On Training Transfer. Human Resource Development Quarterly, 22(1), 111-122. Https://Doi.Org/10.1002/Hrdq.200 63

Lee, H.-Y., \& Wang, N.-J. (2013). The Implementation Of Integrating EProcurment, E-Contracting And EInvoice Platforms For The B2b EMarketplace Web-Based System. International Journal Of Engineering Research, 309(4), 2319-6890.

Https://Pdfs.Semanticscholar.Org/ 9716/57a73eaa741a616af3a9747 eadb008b7bc2a.Pdf

Mar, A. (2016). 87 Soft Skills (The Big List).

Www.Training.Simplicable.Com/Tr aining/New/87soft Skills

Mardiasmo. (2018). Perpajakan. Andi. Http://Andipublisher.Com/Produk0318006543-Special-Price--

Perpajakan-Edisi-Terbaru-.Html

Maria, A., Elim, I., \& Budiarso, N. S. (2018). Analisis Penerapan EFaktur Dalam Prosedur Dan Pembuatan Faktur Pajak Dan Pelaporan Spt Masa Ppn Pada Cv. Wastu Citra Pratama. Going Concern: Jurnal Riset Akuntansi, 13(04), 445-455. Https://Doi.Org/10.32400/Gc.13.03 .20308 .2018

Matteson, M. L., Anderson, L., \& Boyden, C. (2016). "Soft Skills": A Phrase In Search Of Meaning. Portal, 16(1), 71-88. Https://Doi.Org/10.1353/Pla.2016. 0009

Mitchell, G. W. (2010). Essential Soft Skills For Success In The Twenty-
First Century Workforce As Perceived By Alabama Business/Marketing Educators. Auburn University.

Mof. (2014). Central Government General Budget: The Budge Of Fiscal Information Agency, Ministry Of Finance [In Chinese]. Www.Fia.Gov.Tw/Ct.Asp?Xitem=2 $599 \&$ Ctnode $=445 \& M p=1$

Partland, S. And A. A. (2013). How EInvoicing Could Revolutionise Public Sector Procurement. The Guardian.

Https://Www.Theguardian.Com/Pu blic-Leaders-

Network/2013/Jan/14/E-InvoicingPublic-Sector-ProcurementCivilservice

Pazhani, S. S., \& Priya, T. S. (2012). Need For Soft Skills Development Towards Managerial Efficiency. International Journal Of Management Research And Review, 2(11), 1895-1901. Www.ljmrr.Com

Pohan, C. A. (2017). Pembahasan Komprehensif Pengantar Perpajakan Teori Dan Konsep Hukum Pajak Edisi 2. Mitra Wacana Media. Https://Www.Mitrawacanamedia.C om/Pembahasan-KomprehensifPengantar-Perpajakan-Teori-DanKonsep-Hukum-Pajak-Edisi-2

Rafinska, K. (2018). Qr Code Dan Fungsinya Dalam E-Faktur. Pt Achilles Advanced Systems. Https://Www.OnlinePajak.Com/Tentang-PpnEfaktur/Qr-Code-Pajak

Rahmawati, R., Wardhana, A., \& Juniar, A. (2018). Pelatihan Penggunaan Aplikasi Perpajakan Berbasis $\mathrm{Hp}$ Android Di Playstore Untuk Perhitungan Dan Pelaporan Pajak Bagi Ukm Yang Terdata Pada 
Dinas Perindustrian Dan Perdagangan Kota Banjarmasin. Prosiding, 3, 20-23.

Rao, M. S. (2014). Enhancing Employability In Engineering And Management Students Through Soft Skills. Industrial And Commercial Training, 46(1), 4248. Https://Doi.Org/10.1108/lct-042013-0023

Robles, M. M. (2012). Executive Perceptions Of The Top 10 Soft Skills Needed In Today's Workplace. Business Communication Quarterly, 75(4), 453-465.

Https://Doi.Org/10.1177/10805699 12460400

Saica. (2014). Competency Framework Detailed Guidance For Academic Programmes: Competencies of $A$ $\mathrm{Ca}(\mathrm{Sa})$ At The Point Of The Initial Test Of Competence (Itc) (Assessment Of Core Technical Knowledge). South African Institute Of Chartered Accountants (Saica).

Saunders, V., \& Zuzel, K. (2010). Evaluating Employability Skills: Employer And Student Perceptions. Bioscience Education, 15(1), 1-15. Https://Doi.Org/10.3108/Beej.15.2

Sethi, D. (2018). Self-Facilitation Framework For Developing Soft Skills - Fsiar. Development And Learning In Organizations, 32(6), 5-7. Https://Doi.Org/10.1108/Dlo04-2018-0044

Setyawati, V. A., Susilo, H., \& Dewantara, R. Y. (2016). Analisis Penerapan Sistem Elektronik Nomor Faktur (E-Nofa) Pajak Sebagai Upaya Mencegah Penerbitan Faktur Pajak FIKTIF. Jurnal Perpajakan (JEJAK), 8(1), $1-10$.
Sheeta, S. (2013). Necessity of Soft skills Training for students and professionals. International Journal of Engineering, Business and Enterprise Applications, 4(2), 171174.

Sugiyono. (2019). Metode Penelitian Pendidikan. Alfabeta.

Sukardji, U. (2015). Pokok-pokok PPN (Pajak Pertambahan Nilai) Indonesia. Raja Grafindo Persada. http://www.rajagrafindo.co.id/prod uk/pokok-pokok-ppn/

Sukowidyanti, A. P., Nurlaily, F., \& Aini, E. K. (2019). Pengembangan dan Pelatihan Perpajakan Games Edukasi Perpajakan Untuk Meningkatkan Kesadaran Pajak Early Tax Payer. JIPEMAS: Jurnal Inovasi Hasil Pengabdian Masyarakat, 2(1), 18. https://doi.org/10.33474/jipemas.v 2i1.1637

Tran, T. T. (2013). Limitation on the development of skills in higher education in Vietnam. Higher Education, 65(5), 631-644. https://doi.org/10.1007/s10734012-9567-7

Truong, H. T. T., \& Laura, R. S. (2015). Essential Soft skills for Successful Business Graduates in Vietnam. Sociology Study, 5(10), 759-763. https://doi.org/10.17265/21595526/2015.10.001

Vrček, N., \& Magdalenić, I. (2011). Methodology and software components for e-business development and implementation: Case of introducing e-invoice in public sector and SMEs. Journal of Cases on Information Technology, 13(3), 39-61. https://doi.org/10.4018/jcit.201107 0103

Yao, C. W., \& Tuliao, M. D. (2019). Soft 
p-ISSN : 2599-1418

e-ISSN : 2599-1426

skill development for employability:

A case study of stem graduate students at a Vietnamese transnational university. Higher
Jurnal Pendidikan Ekonomi Undiksha

Vol. 13 No. 2 (2021)

Education, Skills and Work-Based Learning, 9(3), 250-263. https://doi.org/10.1108/HESWBL03-2018-0027 